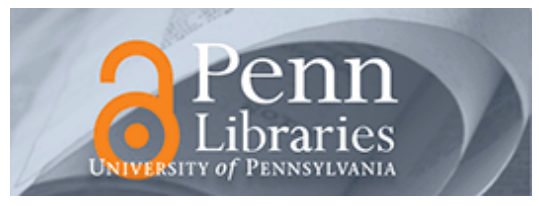

University of Pennsylvania

ScholarlyCommons

Finance Papers

Wharton Faculty Research

$12-2015$

\title{
Trust Promotes Unethical Behavior: Excessive Trust, Opportunistic Exploitation, and Strategic Exploitation
}

Jeremy A. Yip

University of Pennsylvania

Maurice E. Schweitzer

University of Pennsylvania

Follow this and additional works at: https://repository.upenn.edu/fnce_papers

Part of the Finance and Financial Management Commons, and the Social and Behavioral Sciences Commons

\section{Recommended Citation}

Yip, J. A., \& Schweitzer, M. E. (2015). Trust Promotes Unethical Behavior: Excessive Trust, Opportunistic Exploitation, and Strategic Exploitation. Current Opinion in Psychology, 6 216-220. http://dx.doi.org/ 10.1016/j.copsyc.2015.09.017

This paper is posted at ScholarlyCommons. https://repository.upenn.edu/fnce_papers/91

For more information, please contact repository@pobox.upenn.edu. 


\title{
Trust Promotes Unethical Behavior: Excessive Trust, Opportunistic Exploitation, and Strategic Exploitation
}

\author{
Abstract \\ Trust is critical for our cooperation and effective working relationships, but trust also enables exploitation \\ and unethical behavior. Prior trust research has disproportionately focused on the benefits of trust, even \\ though some of the most egregious unethical behaviors occur because of misplaced trust. Targets of \\ exploitation misplace their trust, because they rely on the wrong cues and are exploited by people who \\ either opportunistically or strategically take advantage of their trust. We call for future work to explore the \\ critical link between trust and unethical behavior.

\section{Disciplines} \\ Finance and Financial Management | Social and Behavioral Sciences
}




\title{
Trust Promotes Unethical Behavior
}

\author{
Jeremy A. Yip \\ The Wharton School \\ yip@wharton.upenn.edu
}

Maurice E. Schweitzer

The Wharton School

schweitz@wharton.upenn.edu 


\begin{abstract}
Trust is critical for our cooperation and effective working relationships, but trust also enables exploitation and unethical behavior. Prior trust research has disproportionately focused on the benefit of trust, even though some of the most egregious unethical behaviors occur because of misplaced trust. Targets of exploitation often overweigh the wrong trust cues and are exploited by people who either opportunistically or strategically take advantage of trusting targets. We call for future work to explore the critical link between trust and unethical behavior.
\end{abstract}




\section{Highlights}

- Trust enables unethical behavior

- Targets often misplace their trust because they focus on the wrong cues

- Individuals and organizations exploit trusting targets opportunistically and strategically

- The link between trust and unethical behavior has received far too little research attention 


\section{Trust Promotes Unethical Behavior}

For over a decade, Brian Williams held the coveted position of anchor and managing editor of "NBC Nightly News". In his nightly news broadcast, he drew an average of 9.3 million viewers, winning the top Nielsen ratings for 282 consecutive weeks. The President of NBC News publicly announced that Brian Williams was one of "the most trusted journalists of our time." The network even launched a promotional campaign showing photos of Brian Williams talking to soldiers and children in war zones over the past decade with the narration, "And what you build, if you work hard enough, if you respect it, is a powerful thing called trust."

In early 2015, however, a military newspaper ignited a media firestorm by accusing Brian Williams of misleading the public when he told a fabricated story about coming under enemy fire in a helicopter in Iraq. When it became clear that he had misrepresented his experience, NBC suspended him without pay for six months and launched an internal investigation of the veracity of his reporting during the Iraq War and Hurricane Katrina.

Trust is essential for stable working relationships and economic transactions (Hosmer, 1995). Trust enables many positive outcomes including cooperation (Pillutla, Malhotra, \& Murnighan, 2003), effective leadership (Dirks \& Ferrin, 2002), and coordinated organizational behavior (Zaheer, McEvily, \& Perrone, 1998). The substantial literature has not only documented the benefits of trust (Hurley, 2011), but has also conceptualized trust as a constructive interpersonal force in almost every aspect of our lives (Dirks \& Ferrin, 2002). As Williams' experience shows us, however, just as trust can promote collaboration and coordination, trust can enable exploitation and predation. In fact, many forms of exploitation, such as Ponzi schemes, consumer fraud, and internet scams, involve a critical initial step: building trust. The academic literature has largely neglected the link between trust and 
exploitive, unethical behavior. In this article, we review some of the extant trust research, describe how trust enables unethical behavior, and call for a new stream of research to address the relationship between trust and unethical behavior.

\section{Trust: Ability, Benevolence, and Integrity}

Across disciplines, trust has been defined as the willingness to be vulnerable to exploitation based upon positive expectations (Mayer, Davis, \& Schoorman, 1995; Rousseau, Sitkin, Burt, \& Camerer, 1998). Although the potential for exploitation is a critical element of the definition of trust, we know surprisingly little about the relationship between trust and exploitation. This as a serious oversight.

The dominant trust paradigm presumes that people place greater trust in those they assess to have high ability, benevolence, and integrity (Mayer et al., 1995); according to this framework, individuals are more likely to trust those who have the ability to perform an important task, exhibit benevolence, and have demonstrated integrity. Building on early research, recent trust scholars have distinguished between two primary forms of trust: cognitive trust and affective trust (Lewicki \& Bunker, 1995; McAllister, 1995). Cognitive trust captures the beliefs and expectations that a trustee will be competent and reliable (McAllister, 1995). Cognitive trust is largely influenced by perceptions of the trustee's ability and integrity. Affective trust reflects beliefs about the trustees' care and concern for the trusted party (McAllister, 1995). Affective trust is largely influenced by perceptions of the trustee's benevolence.

Ironically, in some cases, demonstrations of high ability may harm trust and promote unethical behavior. If high performers are salient peers, demonstrations of high performance may actually induce envy, lower trust, and promote unethical behavior (Dunn, Ruedy, \& Schweitzer, 2012; Moran \& Schweitzer, 2008). 
The link between trust and perceptions of ability, benevolence, and integrity is further complicated by the fact that the same action can send conflicting signals about these constructs. For example, prosocial lies, lies that are told to benefit others (e.g., "I find your research interesting.”), can signal high benevolence but low integrity (Levine \& Schweitzer, 2014). Although philosophers and scholars have long argued that deception is unethical and harms trust, prosocial lies can promote trust (Levine \& Schweitzer, 2015). Similarly, accusations of unethical behavior leveled against a third party send mixed signals with respect to benevolence and integrity. By accusing someone of unethical behavior, accusers convey that they have high integrity, but low benevolence. Kennedy and Schweitzer (2015) find that when people accuse a target of engaging in unethical behavior, observers deem the accuser to have higher levels of cognitive trust and the accused to have lower levels of cognitive trust. Kennedy and Schweitzer (2015) conjecture that people may make strategic accusations to manage impressions and build trust.

\section{How Trust Enables Unethical Behavior}

Trust is a critical antecedent for unethical behavior. When individuals misplace their trust in others, they become vulnerable and are more likely to be exploited. Scholars have identified a number of psychological factors that influence unethical behavior (Gaspar \& Schweitzer, 2013; Gino \& Bazerman, 2009; Gino, Norton, \& Ariely, 2010; Gino \& Pierce, 2009; Gino, Schweitzer, Mead, \& Ariely, 2011; Mead, Baumeister, Gino, Schweitzer, \& Ariely, 2009; Moran \& Schweitzer, 2008; Ordóñez, Schweitzer, Galinsky, \& Bazerman, 2009; Ruedy \& Schweitzer, 2010; Schweitzer, DeChurch, \& Gibson, 2005; Schweitzer \& Gibson, 2008; Schweitzer, Ordóñez, \& Douma, 2004; Wiltermuth, Newman, \& Raj, 2015). However, this rich literature has overlooked the critical role of trust in enabling unethical behavior. 


\section{Excessive Trust}

In many cases, people are vulnerable to exploitation because they are simply too trusting. Both individual differences and environmental triggers influence how trusting people are, and both can make people vulnerable to exploitation. With respect to individual differences, we consider trust propensity and naiveté. Trust propensity is a stable individual difference in the willingness to rely on others. Trust propensity has been linked to both trust behavior and risktaking (Colquitt, Scott, \& LePine, 2007; Mayer \& Davis, 1999). The greater one’s trust propensity, the greater the risk of misplacing trust in someone who might exploit it.

A related personality trait is naiveté. Naiveté reflects the failure to consider the strategic and self-interested motives of others (Barasch, Levine, Berman, \& Small, 2014; Tsay, Shu, \& Bazerman, 2011). Naïve individuals are especially likely to be exploited for two reasons. First, naïve individuals trust others too readily. Second, naïve individuals make it easier for exploiters to justify their behavior. Justification is a key antecedent to engaging in unethical behavior (Schweitzer \& Hsee, 2002), and people find it easier to justify their exploitive behavior if they believe that their targets are naïve (Murnighan, Babcock, Thompson, \& Pillutla, 1999).

In addition to individual differences that place some people at particular risk of exploitation, there are environmental cues that place everyone at risk of exploitation. Often, we often rely on the wrong cues to inform our trust beliefs. Superficial cues, such as physical appearance, profoundly influence how much people trust others. For example, individuals are more likely to trust men with wider faces than men with slimmer faces (Stirrat \& Perrett, 2010). And even the clothes people wear influence how much we trust others. Patients in a medical clinic reported higher levels of trust in doctors who wore "white coats" than doctors who did not (Rehman, Nietert, Cope, \& Kilpatrick, 2005). In this case, people were more willing to share 
social, psychological, and sexual problems with physicians who were professionally dressed. That is, outward appearance changes both attitudinal and behavioral trust.

People also trust strangers differently as a result of environmental triggers. For example, superfluous apologies, apologies for things for which the apologizer was clearly not responsible, boost trust (Brooks, Dai, \& Schweitzer, 2014). In one study, commuters in a train station were more likely to hand over their cell phone to a complete stranger who asked to borrow it after the confederated stated, "I'm sorry about the rain." Similarly, incidental emotions, emotions triggered by unrelated situations, influence trust (Dunn \& Schweitzer, 2005; Lount, 2010). When people feel grateful or happy, they may misattribute their positive feelings to their current interactions and, consequently, become more trusting of others.

\section{Exploiting Trust}

Some people build trust with the goal of exploiting trusting targets. In some cases, people are adept at recognizing opportunities to exploit existing trust relationships. In other cases, exploiters manufacture trust relationships that they then exploit. Often, these exploiters seek out vulnerable targets.

One demographic that is particularly vulnerable to exploitation is the elderly. The American Association of Retired People found that senior citizens are more likely to become fraud victims than younger people, and a survey involving the Better Business Bureau revealed that officials perceived a link between a greater willingness to trust and a higher likelihood to become a victim of a scam. For example, in the "grandparent scam," a senior citizen receives a phone call from someone who identifies himself as his/her grandson. The caller claims to have been arrested while travelling in a foreign country. The con artist explains that, "I need your 
help. I need money to pay for bail. But, please don't tell mom and dad because they will get upset." The grandparents who misplace their trust in the caller send money to the con artists. The link between trust and exploitation is particularly clear in cases in which con artists invest time and energy to build trust. For example, con artists frequently manipulate their appearance to gain trust. Related to appearance research and the authority principle of influence (Cialdini, 1985), con artists who dress professionally and present official looking documents often gain trust that they subsequently exploit. In one scam, con artists wearing a company uniform drive a van with a matching company logo into a busy parking lot. The con artist approaches shoppers, claiming that s/he has extra speakers available at a discounted price. Gullible shoppers may purchase speakers that do not even work.

In some cases, con artists appeal to their victims' self-interest with promises of easy money, but request that the target send money in advance. To disarm the target and build trust, exploiters question the trustworthiness of the target (Galinsky \& Schweitzer, 2015). When the exploiter expresses doubt about the target's trustworthiness, the target focuses attention on proving his/her credibility. This happened to John Worley, a psychotherapist, who was swindled by Nigerian con artists. As part of the scam, the Nigerians conducted a background check on Worley, before they "allowed" him to participate. In the end, Worley was swindled out of $\$ 80,000$.

Con artists also exploit social networks to gain trust. Many times, this takes the form of affinity groups. For example, Bernard Madoff founded a brokerage firm that purported to deliver a consistent annual return of at least $10 \%$. Madoff, as a member of the Jewish community, worked closely with prominent Jewish executives and organizations such as the Elie Wiesel Foundation and Steven Spielberg's Wunderkinder Foundation. These reputable foundations lent 
credibility to Madoff and invoked the social proof principle that enabled him to gain the trust of both individual and institutional investors. Though many red flags existed, investors badly misplaced their trust in Madoff. In 2008, the federal authorities discovered that Madoff's brokerage firm was a Ponzi scheme that had lost $\$ 65$ billion! What made this fraud possible? Trust.

\section{Conclusion}

In this article, we conceptualize trust as not only a foundation for creating joint gains through effective leadership and cooperation, but also as a critical antecedent for unethical behavior. Some of the most egregious unethical behaviors occur because individuals exploit trust. Individuals often misplace trust, because they are overly trusting or overweight cues, such as appearance or their current emotional state. And many people hijack the trust of otherseither by recognizing opportunities to exploit misplaced trust or by building trust that they strategically exploit. Trust is critical for our social and economic systems, but it also enables exploitation and unethical behavior. 


\section{References}

Barasch, A., Levine, E. E., Berman, J. Z., \& Small, D. A. 2014. Selfish or selfless? On the signal value of emotion in altruistic behavior. Journal of Personality and Social Psychology, 107(3): 393.

Brooks, A. W., Dai, H., \& Schweitzer, M. E. 2014. I'm Sorry About the Rain! Superfluous Apologies Demonstrate Empathic Concern and Increase Trust. Social Psychological and Personality Science, 5(4): 467-474.

Cialdini, R. 1985. The psychology of influence. New York: William Morrow \& Company.

Colquitt, J. A., Scott, B. A., \& LePine, J. A. 2007. Trust, trustworthiness, and trust propensity: a meta-analytic test of their unique relationships with risk taking and job performance. Journal of Applied Psychology, 92(4): 909.

Dirks, K. T., \& Ferrin, D. L. 2002. Trust in leadership: meta-analytic findings and implications for research and practice. Journal of Applied Psychology, 87(4): 611.

Dunn, J., Ruedy, N. E., \& Schweitzer, M. E. 2012. It hurts both ways: How social comparisons harm affective and cognitive trust. Organizational Behavior and Human Decision Processes, 117(1): 2-14.

Dunn, J. R., \& Schweitzer, M. E. 2005. Feeling and believing: the influence of emotion on trust. Journal of Personality and Social Psychology, 88(5): 736.

Galinsky, A., \& Schweitzer, M. E. 2015. Friend \& Foe. New York: Crown Publications.

Gaspar, J. P., \& Schweitzer, M. E. 2013. The emotion deception model: A review of deception in negotiation and the role of emotion in deception. Negotiation and Conflict Management Research, 6(3): 160-179. 
Gino, F., \& Bazerman, M. H. 2009. When misconduct goes unnoticed: The acceptability of gradual erosion in others' unethical behavior. Journal of Experimental Social Psychology, 45(4): 708-719.

Gino, F., Norton, M. I., \& Ariely, D. 2010. The counterfeit self the deceptive costs of faking It. Psychological Science.

Gino, F., \& Pierce, L. 2009. Dishonesty in the name of equity. Psychological Science, 20(9): 1153-1160.

Gino, F., Schweitzer, M. E., Mead, N. L., \& Ariely, D. 2011. Unable to resist temptation: How self-control depletion promotes unethical behavior. Organizational Behavior and Human Decision Processes, 115(2): 191-203.

Hosmer, L. T. 1995. Trust: The connecting link between organizational theory and philosophical ethics. Academy of Management Review, 20(2): 379-403.

Hurley, R. F. 2011. The decision to trust: How leaders create high-trust organizations: John Wiley \& Sons.

Kennedy, J., \& Schweitzer, M. E. 2015. Holding People Responsible for Ethical Violations: The Surprising Benefits of Accusing Others, Working Paper. University of Pennsylvania.

Levine, E. E., \& Schweitzer, M. E. 2014. Are liars ethical? On the tension between benevolence and honesty. Journal of Experimental Social Psychology, 53: 107-117.

Levine, E. E., \& Schweitzer, M. E. 2015. Prosocial lies: When deception breeds trust. Organizational Behavior and Human Decision Processes, 126: 88-106.

Lewicki, R. J., \& Bunker, B. B. 1995. Trust in relationships: A model of development and decline. In B. B. Bunker, \& J. Z. Rubin (Eds.), Conflict, cooperation, and justice: Essays inspired by the work of Morton Deutsch. San Francisco: Jossey-Bass. 
Lount, R. B. 2010. The impact of positive mood on trust in interpersonal and intergroup interactions. Journal of Personality and Social Psychology, 98(3): 420.

Mayer, R. C., \& Davis, J. H. 1999. The effect of the performance appraisal system on trust for management: A field quasi-experiment. Journal of Applied Psychology, 84(1): 123.

Mayer, R. C., Davis, J. H., \& Schoorman, F. D. 1995. An integrative model of organizational trust. Academy of Management Review, 20(3): 709-734.

McAllister, D. J. 1995. Affect-and cognition-based trust as foundations for interpersonal cooperation in organizations. Academy of Management Journal, 38(1): 24-59.

Mead, N. L., Baumeister, R. F., Gino, F., Schweitzer, M. E., \& Ariely, D. 2009. Too tired to tell the truth: Self-control resource depletion and dishonesty. Journal of Experimental Social Psychology, 45(3): 594-597.

Moran, S., \& Schweitzer, M. E. 2008. When better is worse: Envy and the use of deception. Negotiation and Conflict Management Research, 1(1): 3-29.

Murnighan, J. K., Babcock, L., Thompson, L., \& Pillutla, M. 1999. The information dilemma in negotiations: Effects of experience, incentives, and integrative potential. International Journal of Conflict Management, 10(4): 313-339.

Ordóñez, L. D., Schweitzer, M. E., Galinsky, A. D., \& Bazerman, M. H. 2009. Goals gone wild: The systematic side effects of overprescribing goal setting. The Academy of Management Perspectives, 23(1): 6-16.

Pillutla, M. M., Malhotra, D., \& Murnighan, J. K. 2003. Attributions of trust and the calculus of reciprocity. Journal of Experimental Social Psychology, 39(5): 448-455. 
Rehman, S. U., Nietert, P. J., Cope, D. W., \& Kilpatrick, A. O. 2005. What to wear today? Effect of doctor's attire on the trust and confidence of patients. The American Journal of Medicine, 118(11): 1279-1286.

Rousseau, D. M., Sitkin, S. B., Burt, R. S., \& Camerer, C. 1998. Not so different after all: A cross-discipline view of trust. Academy of Management Review, 23(3): 393-404.

Ruedy, N. E., \& Schweitzer, M. E. 2010. In the moment: The effect of mindfulness on ethical decision making. Journal of Business Ethics, 95(1): 73-87.

Schweitzer, M. E., DeChurch, L. A., \& Gibson, D. E. 2005. Conflict Frames and the Use of Deception: Are Competitive Negotiators Less Ethical? 1. Journal of Applied Social Psychology, 35(10): 2123-2149.

Schweitzer, M. E., \& Gibson, D. E. 2008. Fairness, feelings, and ethical decision-making: Consequences of violating community standards of fairness. Journal of Business Ethics, 77(3): 287-301.

Schweitzer, M. E., \& Hsee, C. K. 2002. Stretching the truth: Elastic justification and motivated communication of uncertain information. Journal of Risk and Uncertainty, 25(2): 185201.

Schweitzer, M. E., Ordóñez, L., \& Douma, B. 2004. Goal setting as a motivator of unethical behavior. Academy of Management Journal, 47(3): 422-432.

Stirrat, M., \& Perrett, D. I. 2010. Valid facial cues to cooperation and trust male facial width and trustworthiness. Psychological Science, 21(3): 349-354.

Tsay, C.-J., Shu, L. L., \& Bazerman, M. H. 2011. Naivete and cynicism in negotiations and other competitive contexts. The Academy of Management Annals, 5(1): 495-518. 
Wiltermuth, S. S., Newman, D. T., \& Raj, M. 2015. The consequences of dishonesty. Current Opinion in Psychology, 6: 20-24.

Zaheer, A., McEvily, B., \& Perrone, V. 1998. Does trust matter? Exploring the effects of interorganizational and interpersonal trust on performance. Organization Science, 9(2): 141-159. 